\title{
KÓPHÁZA - SZÉLES FÖLDEK, OR FROM PREHISTORY TO THE SECOND WORLD WAR
}

\section{FERENC UJVÁRI}

Hungarian Archaeology Vol. 8 (2019), Issue 3, pp. 20-27, https://doi.org/10.36338/ha.2019.3.5

Preventive excavations have been ongoing since May of 2018 at the merged archaeological site under the name Kópháza - Széles földek, and several sections of cemeteries and settlements have been discovered during these. Several thousand features that can be dated from the Copper Age to the modern period have been found over this extensive area. The graves from the Middle Bronze Age, Hallstatt period, Late Iron Age and Early Imperial period have provided interesting details about the history of the region. The Imperial period section of the cemetery can probably be linked to the Germanic Quadi people.

The Rómer Flóris Museum of Art and History in Györ performed preventive excavations on the area of the merged archaeological site of Kópháza-Széles földek during the course of 2018 in connection with the earthwork for the section of the M85 motorway running from Csorna to the eastern section of Sopron. During these, the profile of an extraordinarily intensive archaeological site of several periods has taken shape that includes cemeteries, settlements and lone graves. We have investigated more than 2,200 features in its area of $29489 \mathrm{~m}^{2}$ (Fig. 1).

Trial excavations were performed on this site between Sopron and Kópháza in the autumn of 2017 - or rather on the individual site sections prior to

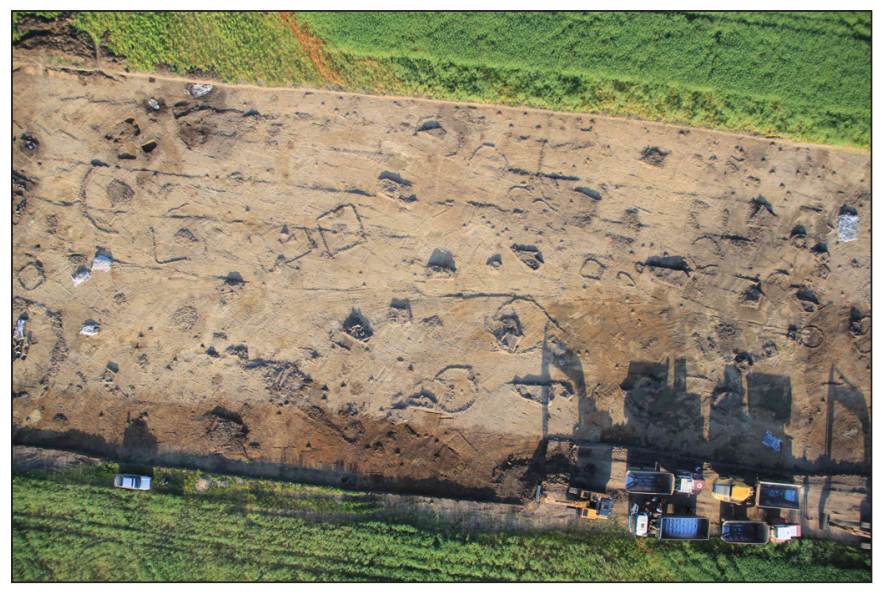

Fig. 1. The cemetery section during the removal of the humus layer (photo by Aeroart - Légikép Ltd) their being merged as one site. During these, a few Early and Late Iron Age graves were also excavated, and based on this we expected an extensive Iron Age cemetery or cemeteries. The preventive excavation thoroughly modified this image.

The removal of the humus layer on the area was performed alongside constant metal detection, and a great amount of metal materials was collected as a result of this. This method proved to be essential, because a large portion of the cremation graves were located or began high, in the humus layer, and hardly sunk into the subsoil, so without collection using metal detectors a large portion of the graves would have been destroyed or highly damaged during humus removal. ${ }^{1}$

We began the excavation of the site in May of 2018. Several factors made the work more difficult, including the intensity of the site, the high gravel and clay content of the subsoil, the stone stacking and the high ground water level during the entire time of the excavation. The constant battle with water hindered the excavation of deep graves and other features to a great extent, which was particularly true of the Middle Bronze Age and Late Iron Age inhumation graves.

This extensive site contained both settlements and cemeteries, and in addition - as was noted in the introduction - these were from several periods. The cemeteries (Middle Bronze Age, Early Iron Age, Late Iron Age, Roman period) are located in the southern portion of the site, while the settlement area is to the north of the cemetery with an overlap with its northern section. The burials in most periods included stacked

The metal detection and humus layer removal were performed by the archaeological technicians Tamás Horváth and Gábor Scherer. Besides them, colleagues performing the excavation were the archaeological technicians Gábor Nagy and György Szabados. János Hatos, Dorina Molnár and Pál Kovács (Lekri Ltd and Archeodata Ltd) also assisted in the excavation. I would hereby like to thank them for their work. 
Ferenc Ujvári • Kópháza - Széles földek, or from Prehistory to the Second World War

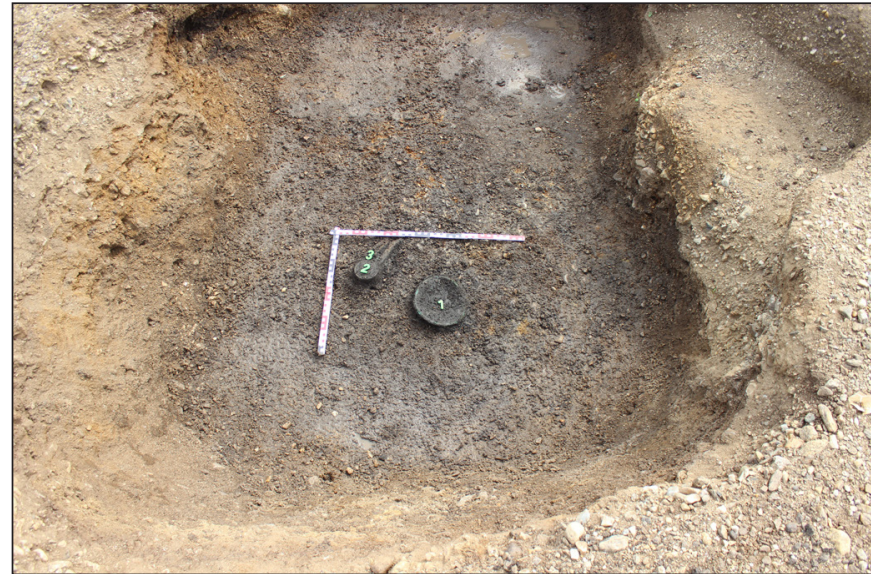

Fig. 2. The grave goods of grave 315 with the single bone fragment in the grave (photo by György Szabados)

stones, and there was stone stacking of some form in graves of the Middle Bronze Age and the Early and Late Iron Age. In the case of the Bronze Age graves, stone stacking sometimes appeared over the entire width and depth of the grave pit.

The graves that can be dated to the Middle Bronze Age are located unsystematically scattered throughout the southern and middle parts of the cemetery section. Their orientation also varies, and even without human remains that can be evaluated, the orientation of the body can sometimes be concluded based on the grave goods. According to this, the main direction was southwest to northeast, but an orientation opposite this also occurs, as do graves oriented in a north-south direction. The graves are inhumation burials, although the surviving number of bones is few and/ or they are in extremely bad condition in the majority of them. (Fig. 2). An exception to this is grave S-1175. The structural bones found there in a non-anatomical arrangement were presumably from several individuals (Fig. 3). Two cremation burials can also be included here theoretically. ${ }^{2}$ Thus, 7-9 graves belong to this

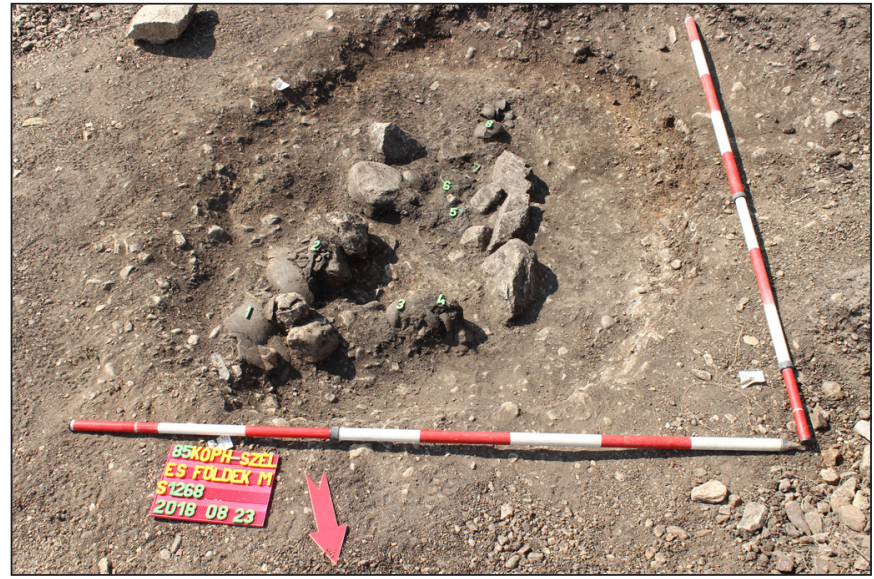

Fig. 4. Grave 1268 with stacked stone, skeletal remains and grave goods (photo by György Szabados)

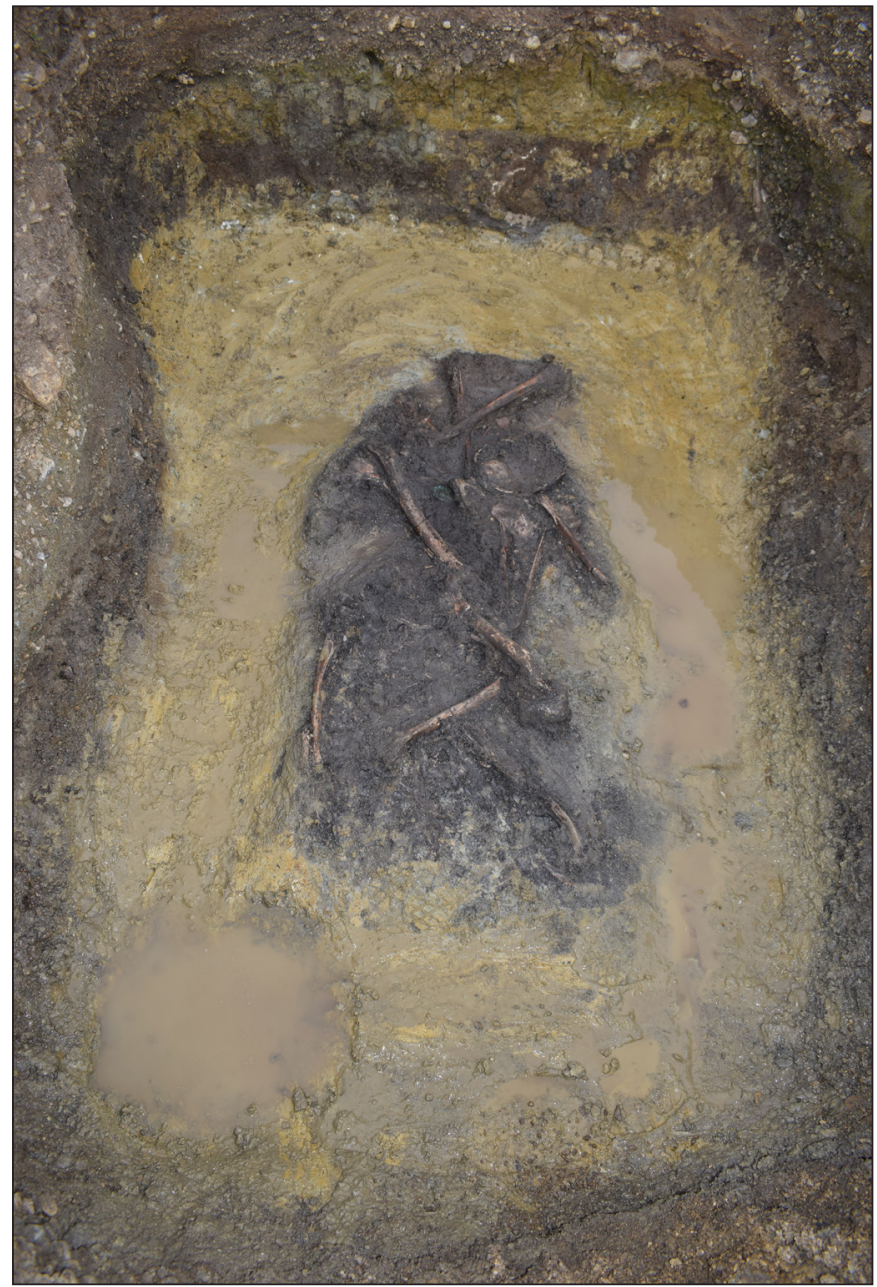

Fig. 3. Grave 1175 (photo by Tamás Horváth)

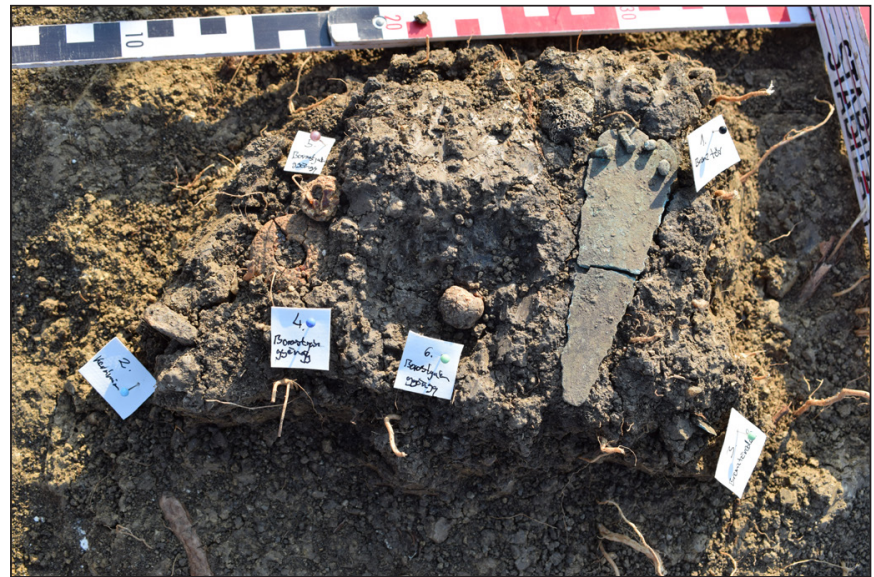

Fig. 5. The grave goods of grave 1625 (photo by Tamás Horváth)

2 Besides the ashes from this small grave pit, there were only vessel fragments. Following their restoration, it will be possible to date them with more certainty and categorize them from a cultural perspective. 
Ferenc Ujvári • Kópháza - Széles földek, or from Prehistory to the Second World War

period in total. The inhumation graves were either deep, with stacked stones for their entire depth, or were relatively shallow, with the stones being placed in them according to a certain system (Fig. 4). I would like to point out in particular grave S-1625, which was discovered during observation slightly outside the excavation area to the south of the site, and was directly below the root zone. The rectangular grave pit barely extended into the subsoil, and its form could only be understood with uncertainty. The finds and the human remains were discovered in a pile at the northwestern part of the grave. They included three amber beads of varying sizes, small ceramic fragments, small bronze fragments and a dagger with four rivets alongside small bone fragments (Fig. 5). During the removal of the humus layer, a flanged axe was discovered, which in all likelihood can be considered a part of the grave goods.

On the basis of the metal and ceramic grave goods - torques (necklaces), arm coils, daggers and hair rings - the graves can be dated to between 2100 $\mathrm{BC}$ and 1700/1600 BC and placed in the Gáta-Wieselburg culture. ${ }^{3}$ It is perhaps worthwhile to note that the hair rings were only found in the shallow graves.

The next cemetery in the chronology belongs to the Early Iron Age Hallstatt culture. The graves from this culture were discovered in the southern half of the cemetery section. The common characteristic of these exclusively cremation burials is that they are located relatively high up, at the bottom of the humus layer or just slightly sunk into the subsoil. In addition, they have few metal finds, but are rich in ceramic grave goods. Unfortunately, the vessels are for the most part in poor condition, and were often found crushed.

A total of 17-22 graves were uncovered from this period. ${ }^{4}$ The exterior surfaces of the large urns were decorated with incised triangles, zig-zag lines and cross-hatched triangles, and sometimes they were decorated with sgraffito (Fig. 6). Small saucers or cups were often found at the bottom, on the ashes. Besides the urns, there were platters, pots and cups that were placed in the grave. In several cases, post holes indicating a grave structure were also

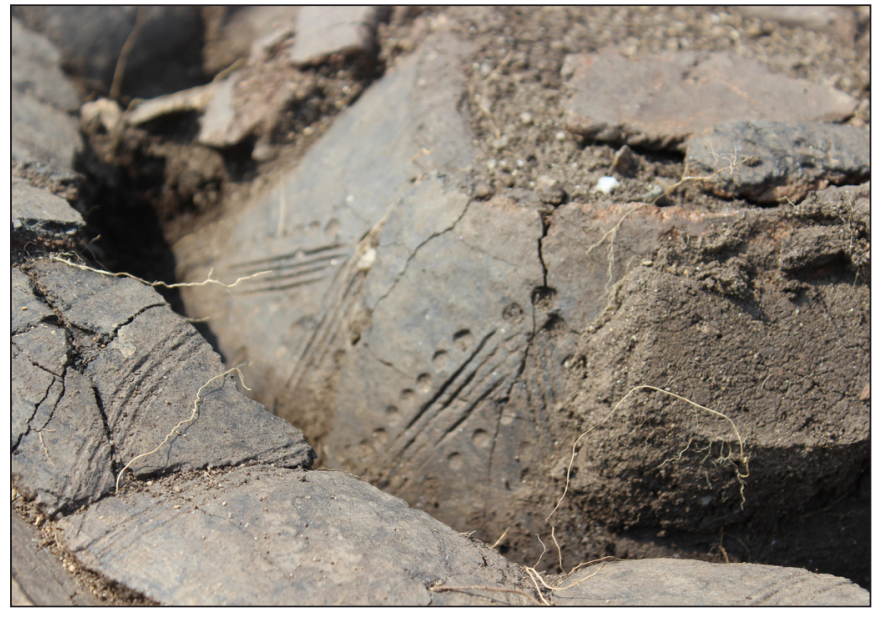

Fig. 6. The decoration from one of the urns of grave 1155 (photo by György Szabados)

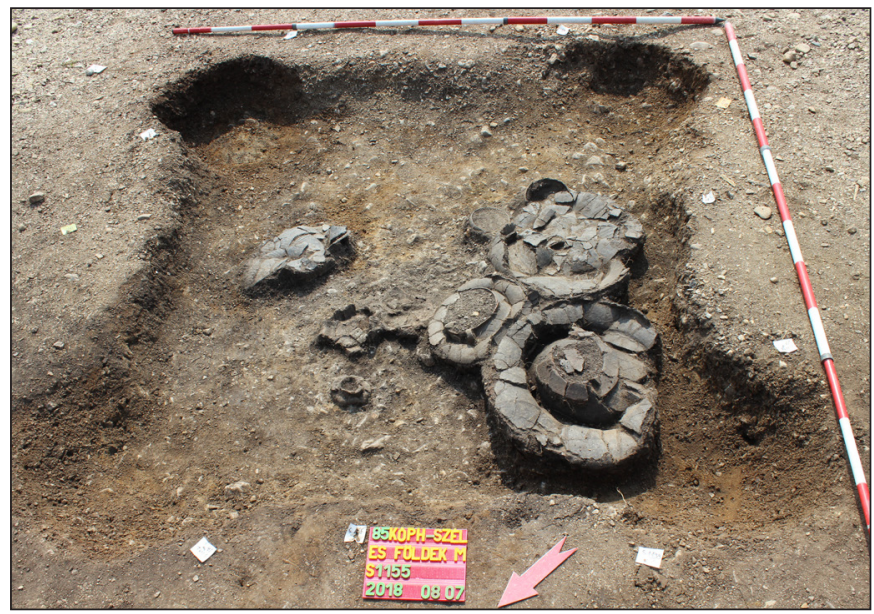

Fig. 7. Grave 1155 with post holes at its corners (photo by György Szabados)

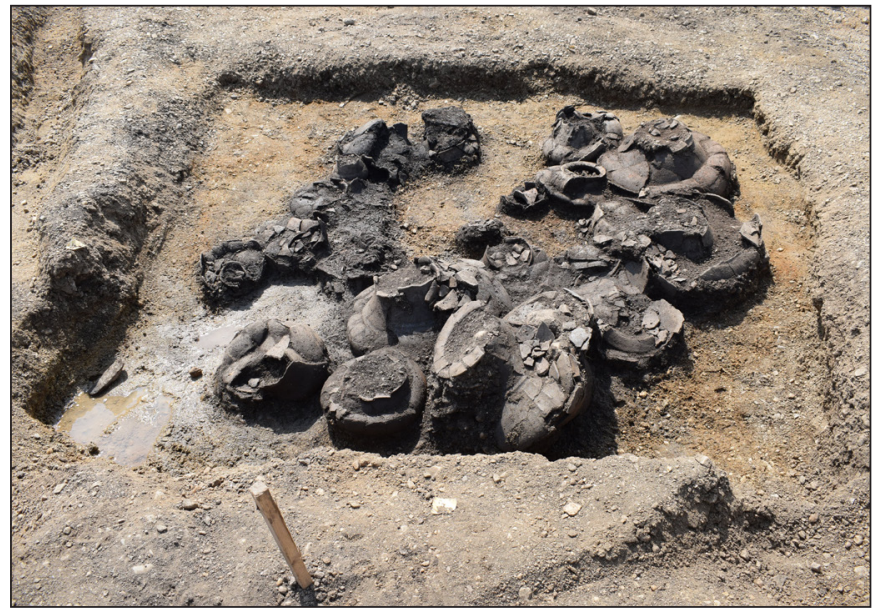

Fig. 8. Grave 198 (photo by György Szabados)

\footnotetext{
The research into the Gáta-Wieselburg culture in Hungary has received new impetus due to the sites that have been discovered and excavated in recent years: e.g. Zsennye - Kavicsbánya (NAGY, 2013, pp. 75-173); and Nagycenk-Lapos rét (GöMÖRI et al., 2018, pp. 5-82). Most recently, an outstandingly rich cemetery from this culture was discovered at the Nagycenk - Farkasverem site during test and preventive excavations led by Attila Mrenka and Bálint Savanyú in connection with the construction of the M85 motorway.

4 The uncertainty arises from the poor condition of a few cremation burials high in the soil and the scanty grave goods. Following restoration and cataloguing it will be possible to determine the precise number of graves.
} 
Ferenc Ujvári • Kópháza - Széles földek, or from Prehistory to the Second World War

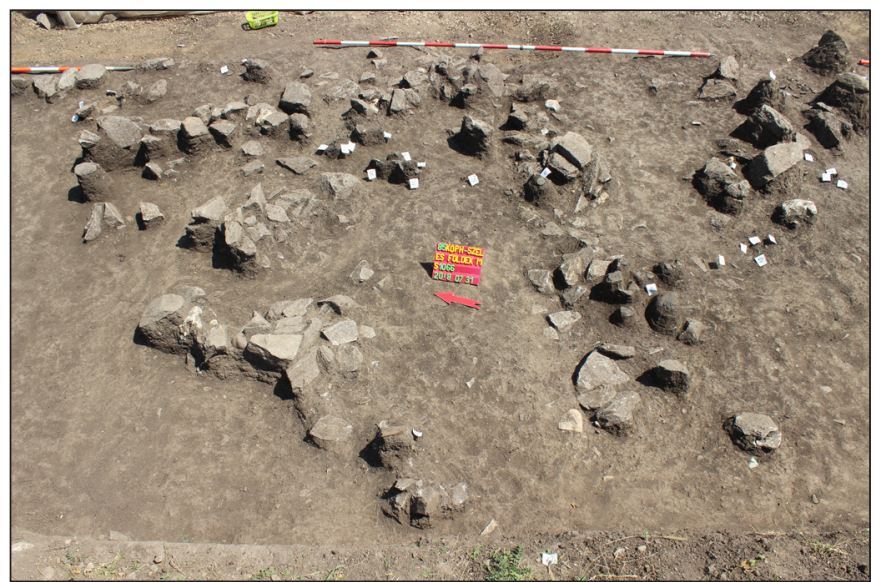

Fig. 9. The upper excavation level of feature 1066 (photograph: György Szabados)

observed. These often were located at the corners of the grave pit, protruding from its plane (S-1118, 1155) (Fig. 7), but they sometimes were located in the bottom of the grave as well (S-1128).

The graves numbered S-1/125 and S-198 stand out from the series of Early Iron Age graves. Besides the urns, a significant number of ceramic grave goods (more than 20 vessels) were discovered in both (Fig. $8)$. The grave number S-1/125 was located at the bottom of the humus layer, barely sunk into the subsoil, and its shorter sides were set with stacked stone. The majority of the decorations that could be observed on the vessels are known from the set of motifs of the Kalenderberg culture. A few graves (S-306, 414, 1128) were surrounded by encircling ditches.

The S-1066 feature bounded by a circular ditch was located outside the excavation area along the western edge of the trench, and is an extensive feature that is difficult to interpret. Its finds and stacked stones were under the current ground level in the humus layer. Ceramic fragments, iron and bronze items and their fragments (iron sword fragments, iron knives, iron javelin with bronze decorations, bronze fibulae, large round bronze buttons, bronze bracelets, iron fittings from equestrian equipment [?], etc.) were discovered amongst unsystematic stacked stones (Figs. 9-10).

The feature S-1066 was excavated and documented at several levels, since the goods and the stones were located atop one another quite densely. The excavated goods could be dated to the Early Iron Age and the Early Imperial period. Human remains (bones, ashes) were not discovered at all during the excavation. The elements of the stacked stone and the goods that could be dated to the Early Iron Age and the Early Imperial period were located randomly within the feature. No digging into the feature could be observed. The most likely interpretation for the feature is that the Germanic people arriving in the area used an Early Iron Age grave or tumulus for burials during the Imperial period, and the later cultivation of the soil disturbed it significantly, moving and damaging the grave goods that lay high in the soil. However, this does not provide an explanation for the lack of human remains.

Presently, the Early Iron Age cemetery can be dated to the Ha C/D1 phases. This will certainly be made more precise during restoration and cataloguing.

The Late Iron Age cemetery is represented by 20 graves. The burials belonging to this period are scattered over a large area and southern and northern grave groups can be differentiated. Their common characteristic 
Ferenc Ujvári • Kópháza-Széles földek, or from Prehistory to the Second World War

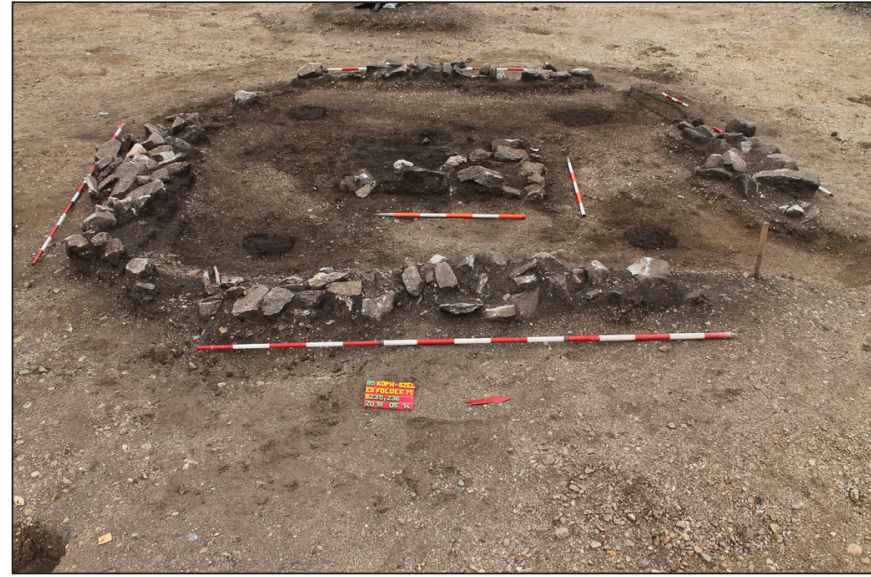

Fig. 11. Grave 235 and its surrounding ditch during excavation (photo by György Szabados)

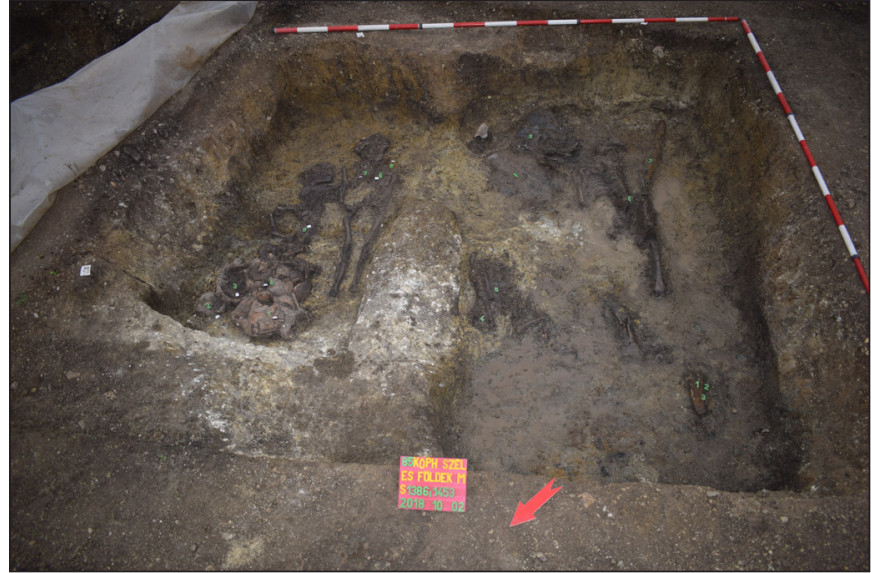

Fig. 12. Graves 1386 and 1453

(photo by Tamás Horváth)

is that they have been extensively looted. Some graves were completely robbed and neither bones nor grave goods have been discovered. For these, it is merely their location and the stacked stone structure that makes it possible to conclude they are from the Late Iron Age, since it was for the most part the sides of the grave that were paved with stone in this period. When bones were found, they were in extremely poor condition. There are two types of rites at the cemetery, as both cremation and inhumation graves have been found, although the inhumation graves dominate. The majority of the burials were oriented to the southeast-northwest, including several - both cremation and inhumation graves - surrounded by rectangular ditches.

Amongst the burials belonging to this period, the cremation burial S-235 and the enclosing ditch S-236 surrounding it should be highlighted. This small cremation burial was completely looted, with only ceramic fragments of varying sizes being found in it. Its peculiar nature is provided by the fact that on the one hand both the grave and the surrounding ditch were paved with stacked stone, and on the other hand post holes were observed in the upper section of the long sides of the grave pit across from one another as well as in the corners of the area enclosed by the surrounding ditch, which suggests a funerary structure (Fig. 11). The S-1352 grave, which held the skeletons of a man and a woman and had been extensively looted but had abundant grave goods, should be mentioned, as should the graves S-18, 1386 and 1453, which were in the area surrounded by deep, wide ditches. The latter two of these, a burial of a man and of a woman, were undisturbed and had ceramic grave goods, animal bones, fibulae and weapons (Fig. 12).

Based on the finds occurring in the graves, the cemetery has been presently dated to the second half of the early phase of the La Tène culture, and it probably continued to be in use during the Middle La Tène period as well (LT B-C1). ${ }^{5}$

The discovery of Early Imperial period graves, in particular in such great numbers, represented the biggest surprise. During the preventive excavation, a total of 60-64 graves came to light. ${ }^{6}$ As has been mentioned, their discovery and observation was not an easy task, since the majority of them were not deep in the humus layer and either had no marks in the soil or poorly discernable marks. The excavation and documentation of the graves containing large amounts of grave goods took place layer by layer.

The majority of the burials belonging to this period are cremations. These for the most part are urn burials or more rarely scattered cremation graves, but there are a few inhumation graves that can also be placed here. They have been found throughout essentially the entire area of the cemetery section, and the only place they do not appear is at the northern end of the area. Sometimes they were encircled with

Few metal materials were found in the looted graves, and these were in quite poor condition. Following the restoration of the objects, a more precise dating can be expected.

6 Scattered cremation burials as well as a few graves with grave goods in poor condition were excavated. Their dating and cultural categorization is uncertain precisely because other communities that performed cremation also made burials in the area. Due to their positions, it is probable that these few graves can also be dated to the Roman period, but it will only be possible to be certain following restoration and cataloguing. 
Ferenc Ujvári • Kópháza - Széles földek, or from Prehistory to the Second World War

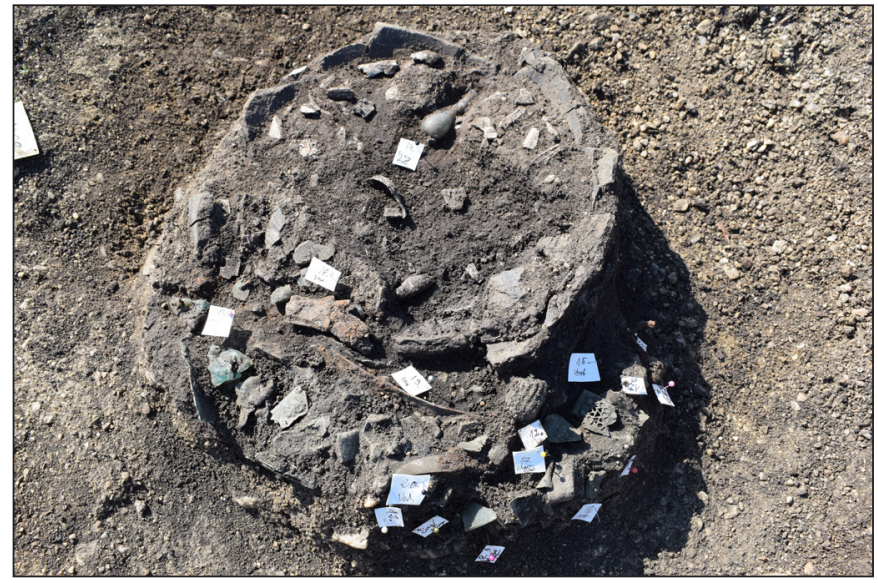

Fig. 13. Grave 1308 (photo by Tamás Horváth)

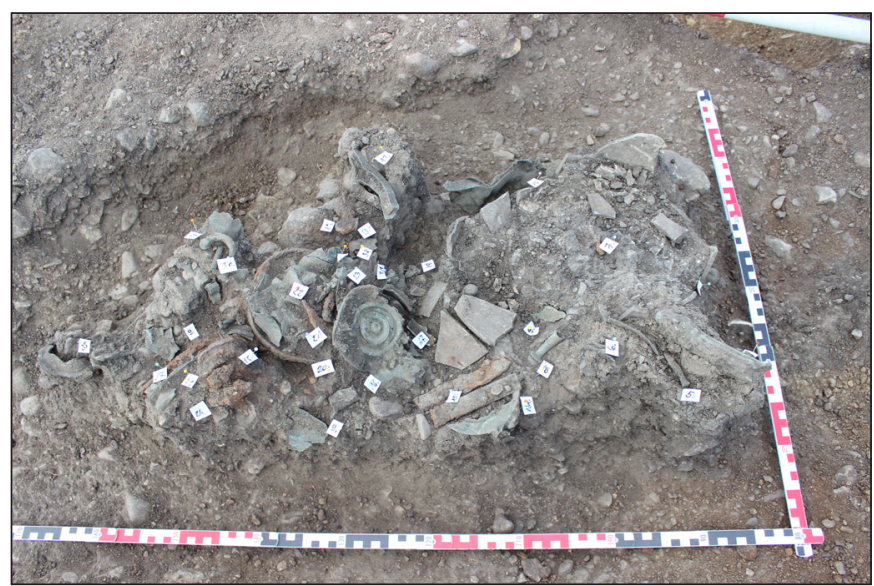

Fig. 15. The rich, cremation-rite man's grave 1216 (photo by Tamás Horváth)

ditches. Based on the grave goods excavated, there is a wide social spectrum present in the cemetery. There are women's graves rich in jewelry and other goods, and men's graves rich in weapons and items of apparel as well as urn or scattered cremation burials that had few grave goods or none at all. ${ }^{7}$

An outstanding example of the rich women's graves is the cremation burial S-1308. A Roman glass vial was discovered in the urn containing the ashes, and there were a bronze fibula, buttons, belt studs, beads, melted glass, fragments of a melted bronze vessel, sheep shears and fragments of iron objects in a pile next to the urn (Figs. 13-14). The rich men's graves held belt studs, melted bronze vessel fragments and melted glass jewelry alongside bent weapons (sword, javelin, shield boss) (Figs. 15-16).

One inhumation grave, which can be placed in this period and was a woman's grave based on the particularly abundant grave goods (S-1261), was excavated under quite adverse circumstances, since the grave

We did not open the urns in it, but took them out intact. Their opening and documentation will take place at the restoration workshop.

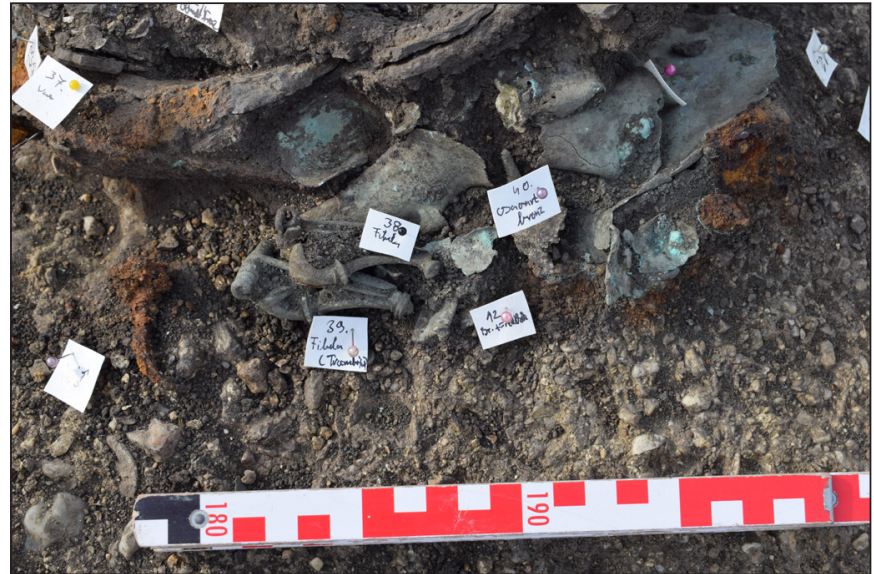

Fig. 14. Detail photograph with fibulae of grave 1308 (photo by Tamás Horváth)

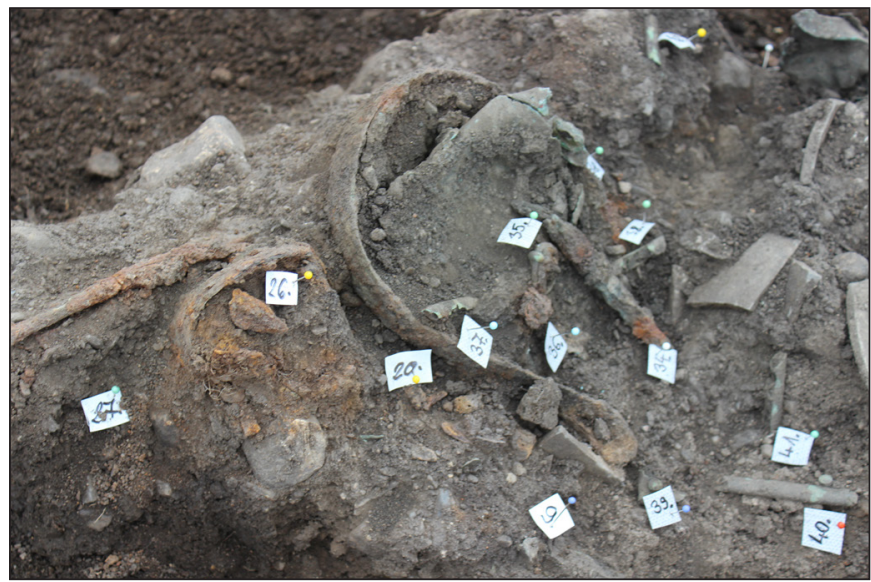

Fig. 16. Detail photograph of the bent sword and its context in grave 1216 (photo by Tamás Horváth)

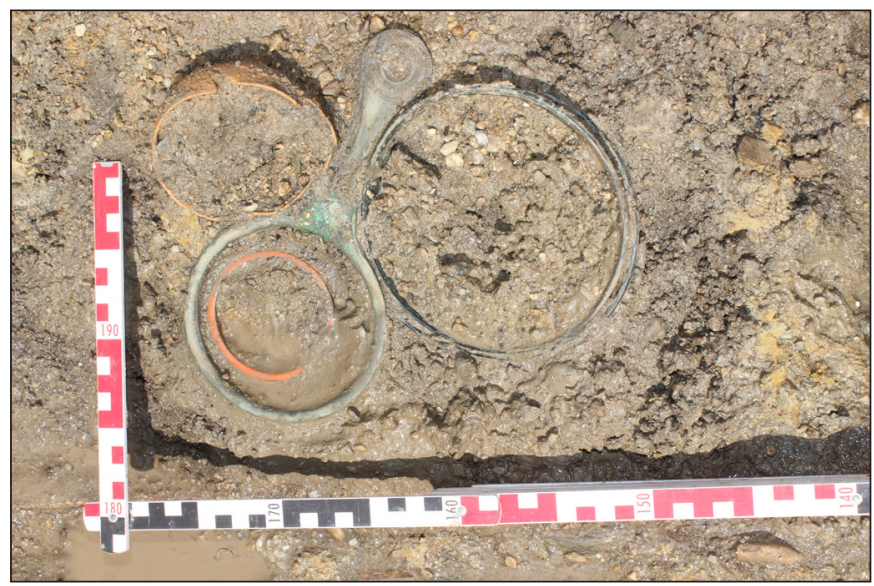

Fig. 17. Dining set in grave 1261

(photo by György Szabados) 
appeared well below the ground water level. On the left side of the skeleton, which was in an extended, supine position oriented to the northwest-southeast, a dining set comprised of a bronze pan, a terra sigillata cup, a thin-walled cup and two fluted glass plates was found (Fig. 17). Several fibulae were also found beside the skeleton.

Thus, Roman find materials were discovered in the graves in large amounts (fibulae, ceramics, bronze vessels), but Germanic elements were also found in high numbers (weapons, fibulae, vessels, belt fittings and belt buckles), just like in the cemeteries excavated to the north of the Danube outside the province of Pannonia in the Quadi area of Barbaricum, such as Ábrahám / Abraham, Egyházfa / Kostolná pri Dunaji, Diószeg / Sládkovičovo (Kolník, 1980), or Kisudvarnok / Malé Dvorníky (ProHÁszKA, 2010). The grave goods from the burials all point in this direction, and in addition, the use of this cemetery seems to be from the same time as the aforementioned cemeteries based on the fibulae, metal vessels and other goods. It can be dated to the middle and second half of the 1st century as well as the beginning of the 2nd century (Stufe $\mathrm{B} 1 \mathrm{bB} 2)$. Based on the numerous analogies, the similar burial rites and the chronological agreement, it is possible to link the Early Imperial period cemetery section in Kópháza to the Quadi as well.

The question arises, what was a foreign ethnic group that arrived with their families, armed with weapons, doing in the province of Pannonia, in the immediate environs of Scarbantia? Perhaps they were auxiliary troops? It is perhaps possible to dismiss this theory, since it was not just the graves of warriors, but also of women and children, as has been mentioned. A more satisfying explanation seems to be that the graves contain the entourage of a ruler that had fallen and been exiled and had been taken in by Rome. This may be indicated by the large number of Roman grave goods, including skyphoi, paterae, fibulae (strong-profiled, trumpet, eyed, etc.), vials, glass platters and terra sigillata cups, since the Quadi living north of the northern border of the province of Pannonia, the Danube, had active relations with the Romans and their ruling class was constantly provided with Roman vessels, jewelry and items for pleasure. However, a grave containing truly abundant objects of precious metal was not found in the cemetery.

The Germanic Quadi settled in the territory of present-day southwestern Slovakia in the middle third of the 1 st century AD. The client kingdom of Regnum Vannianum created by Drusus around 18-19 AD ended in $50 \mathrm{AD}$, since King Vannius was toppled from the throne by his nephews Vangio and Sido. They were also loyal to Rome, and they took his place, dividing the kingdom between themselves. ${ }^{8}$ Tacitus reports that Vannius moved to the territory of the province of Pannonia with his entourage (Annales XII, 2930). Is it possible that we have been able to study the graves of this entourage that settled here? The processing of the find materials will bring us closer to answering this question. ${ }^{9}$

We found settlement features from various periods outside the cemeteries, to the north of them, which due to length restrictions can only be briefly listed here. Traces of Early Bronze Age, Early Iron Age, Roman period and Árpád period settlement were discovered. ${ }^{10}$ In addition to all of this, it is necessary to include the Copper Age as well based on two buildings with foundation trenches, a few stone tools and some ceramic fragments. A few conquest period metal objects were also discovered in the northern section of the site during surveying with metal detectors. A tightly flexed skeleton without grave goods, an extended supine skeleton and the grave of a German soldier from the Second World War were discovered in the settlement area. From all of this, it is possible to see that a truly broad spectrum of history - and eras of prehistory - is presented before us at the Kópháza - Széles földek archaeological site.

8 For the history of the client kingdoms and the Quadi, see: ProHÁszKA, 2008, pp. 22-46.

9 Although the presence of a Quadi cemetery next to Sopron is surprising, items that could be linked to them are known from the area of Lake Fertő/Neuseidl and the Leitha, such as from Eisenstadt and Mannersdorf (BónA, 1963). A similar type of cemetery, perhaps from a bit later was also found at Vinár-Cseralja (MiтHAY, 1989).

10 Object types that can be categorized as from the Vekerzug culture were also found amongst the Early Iron Age settlement features (e.g. rim fragments of wheel-thrown pottery, and stamps). These and the other metal and ceramic types found at the settlement (boat fibula, vessels with ansa lunata handles, carinated bowls, etc.) dates the settlement to a more recent period of the Early Iron Age (Ha D2-3). It seems that the Hallstatt settlement and cemetery are not from the same time. 
Ferenc Ujvári • Kópháza - Széles földek, or from Prehistory to the Second World War

BiBLIOGRAPHY AND RECOMMENDED LiteRATURE

BÓNA, I., 1963.

Beiträge zur Archäologie und Geschichte der Quaden. Acta Archaeologica Academiae Scientiarum Hungaricae 15 (1963), 239-307.

GÖMÖRI, J., Melis, E. \& Kiss, V., 2018.

A cemetery of the Gáta-Wieselburg culture at Nagycenk (Western Hungary). Acta Archaeologica Academiae Scientiarum Hungaricae 69 (2018), 5-82.

Kolník, T., 1980.

Römerzeitliche Gräberfeld in der Slowakei vol. 1. Bratislava: Veda - Verlag der Slowakischen Akademie der Wissenschaften.

Mithay, S., 1989.

A Vinár-cseraljai korarómai temető. Frührömische Friedhof in Vinár-Cseralja. Acta Musei Papensis 2 (1989), 49-75.

NAGY, M., 2013.

Der südlichste Fundort der Gáta-Wieselburg Kultur in Zsennye-Kavicsbánya / Schottergrube, Komitat Vas, Westungarn. Savaria 36 (2013), 75-173.

ProhásZKa, P., 2008.

Imperium et Barbaricum. Kapcsolatrendszerek a Kárpát-medencében a római birodalom és a barbár népek között a római császár- és koranépvándorláskorban. Doctoral dissertation. Budapest, ELTE.

ProhászKa, P., 2010.

Észrevételek a Csallóköz római kori történetéhez avagy új adatok egy feledésbe merült kvád temetőröl. Folia Archaeologica 54 (2010), 205-242.

SzABÓ, M., 2005.

Keleti kelták. Budapest: L'Harmattan. 